\title{
Molecular characterization of the invasive aquatic macrophyte Hydrilla verticillata (Hydrocharitaceae) in Brazil
}

\section{LÉIA CAROLINA LUCIO ${ }^{1,2}$, SIDINEI M. THOMAZ ${ }^{1,3}$, SÔNIA MARIA A.P. PRIOLI ${ }^{1,4}$, TALGE A. BONI ${ }^{1}$, ALESSANDRA V. DE OLIVEIRA ${ }^{1,4}$ and ALBERTO JOSÉ PRIOLI ${ }^{1}$}

\author{
${ }^{1}$ Núcleo de Pesquisas em Limnologia, Ictiologia e Aquicultura, Nupélia, Universidade Estadual de \\ Maringá, Av. Colombo, 5790, Jardim Universitário, 87020-900 Maringá, PR, Brazil \\ ${ }^{2}$ Programa de Pós-graduação em Ciências Aplicadas à Saúde, Universidade Estadual do Oeste do Paraná, \\ Rodovia Vitório Traiano, Bairro Água Branca, 85601-970 Francisco Beltrão, PR, Brazil \\ ${ }^{3}$ Departamento de Biologia, Universidade Estadual de Maringá, Av. Colombo, \\ 5790, Jardim Universitário, 87020-900 Maringá, PR, Brazil \\ ${ }^{4}$ Departamento de Biotecnologia, Genética e Biologia Celular, Universidade Estadual de Maringá, \\ Av. Colombo, 5790, Jardim Universitário, 87020-900 Maringá, PR, Brazil
}

Manuscript received on May 18, 2018; accepted for publication on September 28, 2018

\begin{abstract}
How to cite: LUCIO LC, THOMAZ SM, PRIOLI SMAP, BONI TA, DE OLIVEIRA AV AND PRIOLI AJ. 2019. Molecular characterization of the invasive aquatic macrophyte Hydrilla verticillata (Hydrocharitaceae) in Brazil. An Acad Bras Cienc 91: e20180494. DOI 10.1590/0001-3765201920180494.
\end{abstract}

\begin{abstract}
Invasive populations of macrophytes are widely distributed and have been successfully introduced and established in freshwater habitats. Hydrilla verticillata was first recorded in 2005 in the Upper Paraná River floodplain and in 2007 at the Itaipu Reservoir (Brazil-Paraguay border, ca. $300 \mathrm{~km}$ downstream from its first record). However, its genetic variability within different sites in South America is unknown. We used nucleotide sequences corresponding to the $\operatorname{trnL}-\operatorname{trn} F$ fragment cpDNA to genetically characterize populations of $H$. verticillata in different ecosystems of the Upper Paraná River basin. The results indicated an absence of genetic differentiation within and between populations of the basin, and even individuals collected $600 \mathrm{~km}$ apart belonged to the same haplotype. Moreover, $H$. verticillata populations of the Upper Paraná River basin also matched the dioecious biotype haplotype of the Southern United States and Asia. The identification of this single haplotype suggests that one founder genotype was introduced and established successfully in the Upper Paraná River basin, then, as a consequence of vegetative reproduction and the dispersal of propagules, spread to different habitats. However, firm conclusions about this inference can only be obtained with markers of biparental inheritance.
\end{abstract}

Key words: cpDNA, genetic variability, $\operatorname{trn} L-\operatorname{trn} F$, Upper Paraná River basin.

\section{INTRODUCTION}

Hydrilla verticillata (L.f.) Royle (Hydrocharitaceae), here after hydrilla, is a rootedsubmersed macrophyte that is established in all

Correspondence to: Alessandra Valéria de Oliveira

E-mail: avoliveira@uem.br

ORCid: https://orcid.org/0000-0002-1342-4545 continents except Antarctica, most likely native to warmer regions of Asia, the Pacific Islands, eastern and northeastern Australia and Africa (Cook and Lüönd 1982). This species can be dioecious or monoecious and has a variety of reproductive strategies (e.g., fragmentation, production of turions, tubers and seeds) that enhance its 
establishment (Van 1989, Steward 1993, Langeland 1996). Attributes such as resistance organs, wide ecological amplitudes, high growth rates, high dispersion ability and the capacity to acquire and utilize resources at low levels provide hydrilla a high potential to successfully invade different habitats (Langeland 1996, Sousa 2011). This species spreads rapidly and infests large areas with dense biomass stands often resulting in important effects on abiotic and biotic environmental characteristics (Sousa 2011). Because hydrilla is highly invasive and can cause severe economic and ecological damages, it has raised great concerns from ecologists and environmental managers.

In the Americas, hydrilla was first recorded in North America in 1960 (Cook and Lüönd 1982, Cook 1985). However, the exact time when this species was first introduced in South America, more specifically into Brazilian inland waters, is unknown. It was reported for the first time in the Porto Primavera Reservoir (Upper Paraná Basin, Southeast Brazil) in March 2005 (Anderson et al. 2005) and in the Upper Paraná River floodplain (Sousa 2011), in a site at ca. $30 \mathrm{~km}$ downstream from this reservoir (S. M. Thomaz, personal observation) in June 2005. Hydrilla spread very quickly in the Paraná River basin and by January 2007 it was recorded in the Itaipu Reservoir, at a site ca. $300 \mathrm{~km}$ downstream from its first record (Thomaz et al. 2009). After the recent invasion of the Paraná River watershed, other ecologically and socially important aquatic systems in Brazil became more susceptible to invasion by hydrilla (Sousa 2011). This is a matter of concern due to the potential effect of hydrilla invasion on the highly diverse aquatic ecosystem of this region.

The origin of hydrilla has been investigated using molecular analyses in several regions, e.g., in the United States (Ryan et al. 1995, Madeira et al. 1997, 1999), New Zealand (Hofstra et al. 2000), and South Africa (Madeira et al. 2007). However, its origin as well as its genetic variability within different ecosystems in South America, are unknown. China is most likely the central area of genetic diversity for hydrilla, and this species probably originated in East Asia from where it dispersed throughout the world (Zhu et al. 2015). In contrast to native populations, low levels of genetic diversity have been reported for invasive aquatic species, most often attributed to events that cause population bottleneck (Amsellem et al. 2000, Li et al. 2006, Lambertini et al. 2010). However, lack of variability in hydrilla may also be due to the high degree of vegetative reproduction (Zhu et al. 2015) and/or the presence of only one dioecious sex and absence of sexual reproduction in invasive populations, as for example, in North America (Steward 1993).

In this study, we determined the genetic variability, at the haplotype level, of hydrilla recently introduced in the Upper Paraná River basin in Brazil. We analyzed accessions from several natural and artificial (reservoir) habitats, applying the region of the $t r n L$ intron and the $t r n L F$ intergenic spacer (trnL-trnF) of the chloroplast DNA. Because hydrilla was first recorded in the Upper Paraná River basin, we hypothesize that accessions found in habitats distributed in a large spatial scale (ca. $600 \mathrm{~km}$ along the river) are homogeneous, indicating a common source of this species in this basin.

\section{MATERIALS AND METHODS}

\section{STUDY AREA AND SAMPLING}

A total of 24 samples were taken in five distinct locations in the Upper Paraná River basin: Ilha Solteira Reservoir (Paraná River) $(n=1)$, Três Irmãos Reservoir (Tietê River) $(\mathrm{n}=3)$, Porto Primavera Reservoir (Paraná River) $(n=2)$, channels and floodplain lakes connected to the Paraná River $(\mathrm{n}=10)$ and Itaipu Reservoir (Paraná River) $(n=8)$. The distance between the two furthermost sampling stations within these stations is of ca. 600 
$\mathrm{km}$. The plants were collected manually or with rakes. All samples were carried to the laboratory in plastic bags with water, inside an ice box and were maintained until the time of the extraction.

Genomic DNA from each sample was isolated according to an adaptation of the protocol from Lodhi et al. (1994). The purified DNA was quantified using agarose gel $(0.8 \%)$ electrophoresis and stored in an ultracold $\left(-80^{\circ} \mathrm{C}\right)$ freezer.

AMPLIFICATION OF cPDNA SEQUENCES, SEQUENCING AND GENBANK SEQUENCES

The trnL-trnF fragment was amplified by PCR (Polymerase Chain Reaction) with a pair of specific primers: $t r n-c-F$ and $t r n-f-R$ (Holt et al. 2004). Amplification reactions were in a volume of $25 \mu \mathrm{L}$, with Tris- $\mathrm{KCl}$ buffer (20 $\mathrm{mM}$ Tris- $\mathrm{HCl} \mathrm{pH} 8.4$ and $50 \mathrm{mM} \mathrm{KCl}), \mathrm{MgCl}_{2}$ (2.5 mM), $1.5 \mu \mathrm{M}$ of each primer (trn-cF, 5'-GGAAATCGGTAGACGCTACG-3 ', trn-fR, 5'-ATTTGAACTGGTGACACGAG-3'), dNTP (0.1 mM of each), $1 \mathrm{U}$ of Taq DNA polymerase and $15 \mathrm{ng}$ template DNA. PCR amplifications were carried on MJ Research PTC-100 thermal cycler and comprised a cycle of four minutes at $92^{\circ} \mathrm{C}, 40$ cycles at $94^{\circ} \mathrm{C}$ for 15 seconds, $59^{\circ} \mathrm{C}$ for 30 seconds and $72^{\circ} \mathrm{C}$ for two minutes, followed by a final extension of $72^{\circ} \mathrm{C}$ for ten minutes. Negative controls were also included in each set of amplifications.

Aliquots of the reaction product from each sample were visualized, measured and photographed by routine methodology (Madeira et al. 2004). The products of PCR were purified according to the protocol of Rosenthal et al. (1993) and sequenced separately with the primers trn-c-F and trn$f-R$, using the MegaBace platform (Amersham), following the instruction of the manufacturers. In addition to the sequences generated in this work, other sequences of hydrilla for the cpDNA region trnL-trnF were obtained from GenBank.

\section{DATA ANALYSIS}

The sequences from Upper Paraná River and those taken from GenBank (Hydrilla verticillata haplotypes native and introduced wordwide, $n=41$ ) were edited manually with the program BioEdit (Hall 1999) and aligned with MAFFT using the site https://www.ebi.ac.uk/Tools/msa/mafft/. Gaps with two or more base pairs were coded as single mutation events and when overlapping indels occurred, the overlap portion was considered a single event, according Zhu et al. (2015). The number of polymorphic nucleotide and indels were calculated with DnaSP 5.1 (Librado and Rozas 2009). The distances- $p$ (percentage of polymorphic sites) among all haplotypes of hydrilla, taken two by two, were calculated with the program MEGA 6 (Tamura et al. 2013).

\section{RESULTS}

Fragments of 1132 bp corresponding primarily to the $\operatorname{trnL}$-trnF region of 24 samples of hydrilla collected in the Upper Paraná River basin were compared with 41 samples taken from GenBank. Among the individuals collected in the Upper Paraná River basin, neither base substitutions nor deletions were found and all present the same haplotype. Among the samples from the Paraná basin that were compared to those from GenBank, 13 base changes and 81 deletions were observed. The sequences were collapsed into 14 haplotypes (Supplementary Material - Table SI).

The haplotype that characterized hydrilla from the Upper Paraná basin corresponds to a haplotype identified by Madeira et al. (2007), which includes the dioecious accessions of hydrilla from the United States (Florida, California, Louisiana and Texas) and some locations of Asia: India (Bangalore, Kashmir, New Delhi, Rajasthan), China, Nepal North Vietnam and Pakistan. The p-distance (the proportion ( $p$ ) of nucleotide sites at which two 
sequences being compared are different) between the haplotype from these regions and our haplotype was equal to zero. In addition, this haplotype includes sequences identified by Zhu et al. (2015) in southern part of East Asia (Haplotypes B1/H1 Table SI).

Among haplotypes collected in the Paraná basin and those from the GenBank, the p-distance values ranged from zero to 0.018 . Excluding those accessions identical to ours, the accessions that showed the lowest p-distance values compared to the ones from the Upper Paraná basin were KM982399 (Haplotype H2/B2) (Lake Tanganyika Burundi/south of Yangtze River, China) and EF458072 (Haplotype H4) (L.Cairns, Queensland, Australia) $(p$-distance $=0.001)($ Figure 1). The highest $\mathrm{p}$-distance values compared to the Upper Paraná basin were from the accessions EF458053 (Haplotype H8) (Kobe, Japan) and EF458054 (Haplotype H9) (Lake Krulak, Poland), equal to 0.018 and 0.017 , respectively (Figure 1 ).

\section{DISCUSSION}

The results indicated an absence of genetic differentiation at the haplotype (phylogenetic) level within and between populations in the Upper Paraná River basin and even individuals collected $600 \mathrm{~km}$ apart. Because we found a single haplotype in the Upper Paraná basin, we suggest that this region was invaded by hydrilla originating from a common source. This introduction history differs from the one of hydrilla in the North America, where the first introduction was the dioecious female biotype, in 1950, from Sri Lanka (Southeast Asia) into Florida (Schmitz 1990). Later, in 1976, the monoecious biotype was introduced into the State of Delaware and, subsequently, into the Potomac River, Washington, D.C. (Haller 1982, Steward et al. 1984, Anderson 1996, Madeira et al. 2004). Currently, populations of dioecious and monoecious biotype are also present in other US states (Madeira et al. 2000, 2007, True-Meadows et al. 2016). The monoecious biotype generally shows a more northern distribution in the USA while the dioecious hydrilla occurs mostly in the Southern Atlantic and Gulf basins (Figure 1).

Hydrilla samples from the Upper Paraná basin presents the same haplotype as dioecious plants from the United States and Asia and, for this reason, it is not possible to determine objectively the origin of hydrilla in Brazil. This information could possibly be obtained with more sensitive markers such as microsatellites. However, the proximity between the USA and Brazil and the greater exchange of people and commerce between them, as compared with Asian countries (Embratur 2005), would favor the argument that propagules from the USA were introduced in Brazilian ecosystems. Besides that, Florida is a traditional center of ornamental aquaculture farming and trade (Chapman et al. 1997).

The genetic diversity in aquatic plants is generally lower than in terrestrial plants, and it is often identified among populations, and not inside them, due to the dominance of vegetative reproduction (Nakamura and Kadono 2000). Moreover, a population's colonization by a single founder genotype which reproduces via cloning results in populations that are genetically uniform (Burden and Marshall 1981, Hofstra et al. 2000). For example, more than three-fourths of the hydrilla populations sampled throughout China belong to a single haplotype and lack of intra-population variation of these populations seems frequent (Zhu et al. 2015). The absence of variability in the nucleotide sequences of the populations from the Upper Paraná basin, besides indicating that there was a single genotype founder, probably can be a consequence of the maintenance of populations via vegetative reproduction and the dispersal of propagules to the different habitats. Only pistillate flowers of $H$. verticillata have been 


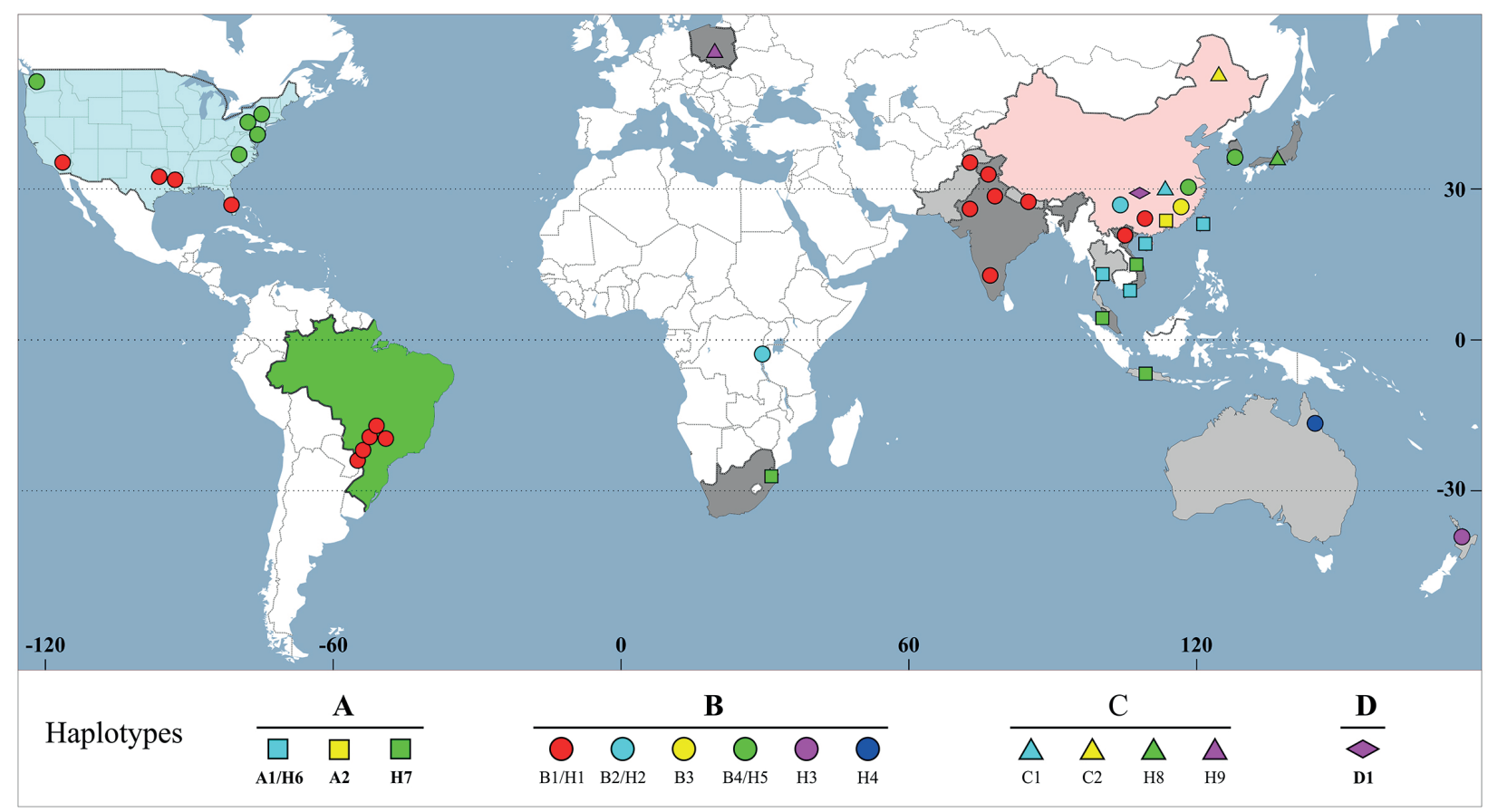

Figure 1 - Distribution of the Hydrilla verticillata haplotypes native and introduced worldwide. Our data (Brazil) compared with world data retrieved from Madeira et al. (2004, 2007) and Zhu et al. (2015).

collected in the Upper Paraná River, providing evidence that all individuals belong to a dioecious female (Sousa 2011) and thus, they are not able to reproduce sexually. In addition, the temporal sequence of invasions going downstream (Porto Primavera Reservoir - Paraná River floodplain Itaipu Reservoir) (Thomaz et al. 2009) is also an indication that dispersal of fragments is the probable means of spread of this plant in the basin. Despite these indications that hydrilla is maintained via vegetative reproduction in the Upper Paraná basin and because cpDNA is of maternal inheritance, firm conclusions about this inference can only be reached with studies involving nuclear genome analysis.

In conclusion, our data supports the hypothesis of a single founder genotype in the introduction of hydrilla to the Upper Paraná, which then spread rapidly becoming a successful invader of a variety of ecosystems distributed over a large spatial scale. The lack of genetic variability in the hydrilla populations found in Brazil has to be taken into account if management is necessary.

\section{ACKNOWLEDGMENTS}

We thank Valmir Alves Teixeira, Sebastião Rodrigues, Alfredo Soares da Silva and Valdenir Ferreira de Souza for field assistance and Comcap (Research Support Centers Complex, University of Maringá) for the sequencings. This work was supported by Itaipu Binacional and the Conselho Nacional de Desenvolvimento Científico e Tecnológico (CNPq), through the Long-Term Ecological Research Program, site number 6.

\section{AUTHOR CONTRIBUTIONS}

LCL, SMT and AJP conceived the work. LCL and SMT collected the samples. LCL conducted the molecular analysis, with the help of TAB, SMAPP and AVO. LCL wrote the first draft of the manuscript, which was critically revised and 
improved by SMT, TAB, AVO, SMAPP and AJP. All authors read the last version of the manuscript.

\section{REFERENCES}

AMSELLEM L, NOYER JL, LE BOURGEOIS T AND HOSSAERT-MCKEY M. 2000. Comparison of genetic diversity of the invasive weed Rubus alceifolius Poir. (Rosaceae) inits native range and in areas of introduction, using amplified fragment length polymorphism (AFLP) marker. Mol Ecol 9: 443-455.

ANDERSON L. 1996. Eradicating California's Hydrilla. Aquat Nuis Spec Digest 29: 31-33.

ANDERSON LWJ, PITELLI RA, CARRUTHERS R, PITELLI RLCM AND FERREIRA WLB. 2005. First Hydrilla found in Brazil: Implications for further dispersal and likely impacts. In: The Aquatic Plant Management Society, $45^{\text {th }}$ Annual Meeting. San Antonio, Texas, p. 56.

BURDEN JJ AND MARSHALL DR. 1981. Biological control and the reproductive mode of weeds. J Appl Ecol 18: 649-658.

CHAPMAN FA, FITZ-COY SA, THUNBERG EM AND ADAMS CM. 1997. United States of America trade in ornamental fish. J World Aquacult Soc 28: 1-10.

COOK CDK AND LÜÖND R. 1982. A revision of the genus Hydrilla (Hydrocharitaceae). Aquat Bot 13: 485-504.

COOK CDK. 1985. Range extensions of aquatic vascular plant species. J Aquat Plant Manage 23: 1-6.

EMBRATUR. 2005. Anuário Estatístico Embratur. htttp// www.turismo.gov.br/dadosefatos (accessed December 2017).

HALL TA. 1999. Bioedit: a user-friendly biological sequence alignment editor and analysis program for Windows 95/98/ NT. Nucl Acids Symp Ser 41: 95-98.

HALLER WT. 1982. Hydrilla goes to Washington. Aquatics 4: 6-7.

HOFSTRA DE, CLAYTON J, GREEN JD AND ADAM KD. 2000. RAPD profiling and isozyme analysis of New Zealand Hydrilla verticillata. Aquat Bot 66: 153-166.

HOLT SDS, HOROVA L AND BURES P. 2004. Indels patterns of the plastid DNA trnL-trnF region within the genus Poa (Poaceae). J Plant Res 117: 393-407.

LAMBERTINI C, RIIS T, OLESEN B, CLAYTON JS, SORRELL BK AND BRIX H. 2010. Genetic diversity in three invasive clonal aquatic species in New Zealand. BMC Genet 11: 52.

LANGELAND KA. 1996. Hydrilla verticillata (L.f.) Royle (Hydrocharitaceae), “The perfect aquatic weed". Castanea 61: 293-304.

LI W, WANG B AND WANG J. 2006. Lack of genetic variation of an invasive clonal plant Eichhornia crassipes in China revealed by RAPD and ISSR markers. Aquat Bot 84: 176-180.
LIBRADO P AND ROZAS J. 2009. DnaSP v5: A software for comprehensives analysis of DNA polymorphism data. Bioinformatics 25: 1451-1452.

LODHI MA, YE GN, WEEDEN NF AND REISCH BI. 1994. A simple and efficient method for DNA extractions from grapevine cultivars and Vitis species. Plant Mol Biol 12: 6-13.

MADEIRA PT, VAN TK, STEWARD KK AND SCHNELL RJ. 1997. Random amplified polymorphic DNA analysis of the phenetic relationships among world-wide accessions of Hydrilla verticillata. Aquat Bot 59: 217-236.

MADEIRA PT, VAN TK AND CENTER TD. 1999. Integration of five southeast Asian accessions into the world-wide phenetic relationships of Hydrilla verticillata as elucidated by random amplified polymorphic DNA analysis. Aquat Bot 63: 161-167.

MADEIRA PT, JACONO CC AND VAN TK. 2000. Monitoring Hydrilla using two RAPD procedures and the nonindigenous aquatic species database. J Aquat Plant Manage 38: 33-40.

MADEIRA PT, VAN TK AND CENTER TD. 2004. An improved molecular tool for distinguishing monoecious and dioecious Hydrilla. J Aquat Plant Manage 42: 28-32.

MADEIRA PT, COETZEE JA, CENTER TD, WHITE EE AND TIPPING PW. 2007. The origin of Hydrilla verticillata recently discovered at a South African dam. Aquat Bot 87: 176-180.

NAKAMURA T AND KADONO Y. 2000. Genetic diversity of the submerged macrophyte Hydrilla verticillata (L. f.) Royle in a river system in Japan. Limnology 1: 27-31.

ROSENTHAL A, COUTELLE O AND CRASETON M. 1993. Large-scale production of DNA sequencing templates by microtitre format PCR. Nucleic Acids Res 21: $173-174$

RYAN FJ, COLEY CR AND KAY SH. 1995. Coexistence of monoecious and dioecious Hydrilla in Lake Gaston, North Carolina and Virginia. J Aquat Plant Manage 33: 8-12.

SCHMITZ DC. 1990. The invasion of exotic aquatic and wetland plants into Florida: history and efforts to prevent new introductions. Aquatics 12: 6-24.

SOUSA WT. 2011. Hydrilla verticillata (Hydrocharitaceae), a recent invader threatening Brazil's freshwater environments: a review of the extent of the problem. Hydrobiologia 669: 1-20.

STEWARD KK, VAN TK, CARTER C AND PIETERSE AH. 1984. Hydrilla invades Washington, DC, and the Potomac. Am J Bot 71: 162-163.

STEWARD KK. 1993. Seed production in monoecious and dioecious populations of Hydrilla. Aquat Bot 46: 169-183.

TAMURA K, STECHER G, PETERSON D, FILIPSKI A AND KUMAR S. 2013. MEGA6: Molecular Evolutionary Genetics Analysis Version 6.0. Mol Biol Evol 30: 27252529. 
THOMAZ SM, CARVALHO P, MORMUL RP, FERREIRA FA, SILVEIRA MJ AND MICHELAN TS. 2009. Temporal trends and effects of diversity on occurrence of exotic macrophytes in a large reservoir. Acta Oecol 35: 614-620.

TRUE-MEADOWS S, HAUG EJ AND RICHARDSON RJ. 2016. Monoecious hydrilla - A review of the literature. J Aquat Plant Manage 54: 1-11.

VAN TK. 1989. Differential responses to photoperiods in monoecious and dioecious Hydrilla verticillata. Weed Sci 37: 552-556.
ZHU J, YU D AND XU X. 2015. The phylogeographic structure of Hydrilla verticillata (Hydrocharitaceae) in China and its implications for the biogeographic history of this worldwide-distributed submerged macrophyte. BMC Evol Biol 15: 95.

\section{SUPPLEMENTARY MATERIAL}

Table SI - A fragment nucleotide polymorphism corresponding to the $t r n L$-trnF region of cpDNA from the $H$. verticillata accessions from Genbank and the Upper Paraná basin (Brazil). Data retrieved from Madeira et al. (2004, 2007) and Zhu et al. (2015). 